\title{
Resistance of Two Eggplant Cultivars Against the Two-Spotted Spider Mite; Tetranychus urticae Koch Infestation, with Notes on its Biology
}

\author{
A.M. Afifi ${ }^{*}$; Shahira M. El-Bishlawy ${ }^{*}$ and Hanady A. A. Mahmoud ${ }^{* *}$ \\ * Dept. of Zoology and Agric. Nematology, Fac. of Agric., Cairo Univ., Giza, Egypt \\ ${ }^{* *}$. ant Protec. Res. Institute, Giza, Egypt
}

\begin{abstract}
Field and laboratory studies revealed that the eggplant Black baity cultivar recorded the highly significant susceptible to infestation with Tetranychus urticae Koch compared with Baity cultivar.Susceptibility of eggplant cultivars to infestation may be affected by plant leaf morphological structure; length, thickness and density of leaf trichomes. Average number of trichomes $/ \mathrm{mm}^{2}$ leaf was 27.7 and 21.6 for Baity and Black baity cultivars, respectively. The highest mean number of T. urticae movable stages on leaves of Black baity cultivar was associated with higher levels of total amino acids and total carbohydrates and with the lowest levels of total phenolic compounds and tannins. Durations of egg, different immature stages, life cycle and life span of $T$. urticae female were the shortest when reared on leaves of Black baity cultivar and the longest on leaves of Baity cultivar. The two eggplant cultivars affected the life table parameters of $T$. urticae. The shortest mean generation time $(\mathrm{T})$ was 12.08 days on Black baity cultivar, and the longest was 13.21 days on Baity cultivar. The highest net reproductive rate $\left(\mathrm{R}_{0}\right)$ was 32.01 females/female on Black baity cultivar, and the lowest was 21.13 females/female on Baity cultivar.
\end{abstract}

Key Words: Eggplant, Tetranychus urticae ,Susceptibility, Trichomes and Life table.

\section{INTRODUCTION}

Eggplant, Solanum: melongena L., (Solanaceae) is a common and popular vegetable crop grown in the subtropical and tropical countries (Filgueira, 2000).In Egypt,the tetranychid mite ;Tetranychus urticae Koch is considered one of the major pests which attack eggplant (Abdallah, 2002 and El-Saiedy \& Romeih, 2007). Evaluation of the susceptibility of some eggplant cultivars to infestation with $T$. urticae in order to select the most resistant ones is considered important to avoid using more pesticides. Chemical contents and morphological characteristics of plant leaves which normally vary according to plant cultivar may affect the population levels of herbivorous pests. There were several studies on the host plant resistance to the infestation with $T$. urticae; (Crooker, 1985,Tomczyk et al., 1987, Ibrahim et al., 2008 , Afifi et al., 2009, Abdallah et al., 2009 and El-Saiedy et al., 2011 ). Karaat (1991) reported that host plants had a more significant effect on reproductive potential of tetranychids than that on developmental rate. Therefore, the present study was conducted to determine the resistance of two eggplant cultivars; Baity and Black baity to infestation with $T$. urticae, also, the mite biology and life table parameters were carried out on leaves of the two eggplant cultivars.

\section{MATERIALS AND METHODS}

Imaging the bottom surface of two eggplant cultivar leaves using the scanning Electron Microscopic technique (SEM) (Joel GM 4200) at the
Applied Center for Entomonematodes (ACE), Faculty of Agriculture, Cairo University. Samples for SEM technique were dehydrated in ethyl alcohol and dried using the critical point procedure, then individually affixed using double sided sticky tape, and sputter coated with gold palladium according to Fashing et al. (2000).

Some specific chemical constituents of eggplant leaves were determined as follow: Total phenol content was determined by Folin- Ciocateu method as modified by Singelton and Rossi (1965).Total carbohydrates were extracted from the plant leaves and prepared for assay according to Crompton and Birt (1967). Total amino acids were calorically assayed by ninhydrin reagent according to the method described by Lee and Takabashi (1966). The amount of Tannins in extracts was determind by Folin- Ciocateu method as modified by Singelton and Rossi (1965). Chemical analysis was carried out during the growing season of the two eggplant cultivars during two periods; peak and late season of infestation. Eggplant leaves were collected and transferred to laboratory and dried under room condition for chemical analysis.

The duration of developmental stages, life cycle, life span, fecundity of T. urticae were studied on the leaves of two eggplant cultivars; Baity and Black baity under laboratory conditions of $25 \pm 1^{\circ} \mathrm{C}$ and $70 \%$ R.H. Eggplant leaf discs ( $2 \mathrm{~cm}$ diameter) with under surface upward, were placed on cotton bed in Foam dish $(20 \mathrm{~cm} \times 15 \mathrm{~cm})$; the cotton bed was kept wet. Ten $T$. urticae adult females collected from the laboratory stock culture were transferred to each disc 
for laying eggs. For solitary rearing, newly deposited eggs of the same age were transferred singly, each to a leaf disc. Every dish contained 25 discs. Dishes with discs were kept in an incubator at temperature of $25 \pm 1^{\circ} \mathrm{C}$ and $70 \%$ relative humidity. Discs of all treatments were examined twice daily and all biological aspects were recorded until death of mite individuals.

Life tables of $T$. urticae were constructed from the life history and fecundity data. The actual death occurred in egg and immature stages was taken into account when the female survival rate at temperature was determined. Life tables were constructed using the survival data of a specific age class $(\mathrm{L} \mathrm{x})$ and the female offspring produced per female in each age class $(\mathrm{m} \mathrm{x})$. The net reproductive rate $\left(\mathrm{R}_{\mathrm{o}}\right)$, the mean generation time $(T)$, the intrinsic rate of increase $\left(r_{m}\right)$, and the finite rate of increase $(\lambda)$ were estimated according to Birch (1948) using the basic computer program of Abou-Setta et al. (1986).

\section{RESULTS AND DISCUSSION}

According to the mean number of Tetranychus urticae movable stages / leaf existed through the two successive seasons; 2011 and 2012, the obtained results show that the tested eggplant cultivars (Baity and Black baity ) significantly $(\mathrm{P}>0.05)$ differed in their susceptibility to infestation with $T$. urticae . Black baity cultivar was the highly significant susceptible to infestation, it recorded the highest infestation numbers (135.54 and 115.03 individuals/ leaf) and the highest infestation percentages $(63.25$ $\& 62.3 \%$ ) during the two successive seasons, respectively; while the lowest infestation numbers and infestation percentages were recorded on Baity cultivar (Table 1). These results were in agreement with those obtained by Ibrahim et al., 2008; Abdallah et al., 2009 and El-Saiedy et al., 2011.

The differences between the two eggplant cultivars in their leaf morphological structure were studied. Leaf trichome consisted of a main branch perpendicular to the leaf surface and the other branches are attached to the main branch in a radiating fashion, parallel or subparellel to the leaf surface with trunk as reported by Patrick et al.,(2000) (fig. 1). Trichomes shape, length and density differed in two eggplant cultivars, Baity cultivar has numerous, longer and thicker trichomes than those of Black baity cultivar. The number of trichomes were 27.7 and $21.6 / \mathrm{mm}^{2}$ for Baity and Black baity cultivars respectively. Also the length of trichomes were 483.94 and $542.63 \mathrm{~m} \mu$ for Baity and Black baity respectively, the highest number of trichomes or the trichomes density in the baity cultivar could be the resistance factor that deter both of $T$. urticae feeding and oviposition. Afifi et al. (2009) and El-Saiedy et al., (2011) reported that length, thickness and density of leaf trichomes affect strawberry plant resistance to infestation with T. urticae.

Obtained results indicated that, positive relationships occurred between mite infestation levels and total amino acids, free total carbohydrates in eggplant cultivars, while negative relationships were found with tannins and nearly shown with total phenolic compounds (Table 2). These results are in agreement with those recorded by; Tomczyk et al., 1987; Leite et al.; 2003 Ibrahim et al., 2008; Abdallah et al., 2009 and Afifi et al., 2009 and El-Seidy et al., 2011.

The two different eggplant cultivars affected the durations of developmental stages as well as adult longevity and female fecundity of $T$. urticae (Table 3 ). Female life cycle averaged 8.72 and 11.62 days, adult longevity averaged 11.08 and 9.63 days when T. urticae was reared on leaves of Black baity and Biaty cultivars respectively. Male showed similar trend of female but with slightly shorter periods. Crooker (1985) indicated that the chemical constitution of the leaf might influence fecundity, mortality and development of the immature stages of spider mites, especially the host plant nitrogen content.

The number of deposited eggs per female and daily rate of $T$. urticcie averaged $43.26 \& 7.09$ and $28.43 \& 5.0$ eggs when reared on leaves of Black baity and Baity respectively. Daily egg production of T. urticae reached its peak on the fourth day on Black baity cultivar ( $9.68 \mathrm{eggs} / \% /$ day), and on the third day on Baity cultivar (6.78 eggs/ $/ /$ day); egg production decreased gradually thereafter. In general, there was no distinct $\mathrm{m}_{\mathrm{x}}$ peak, egg production was distributed over a relatively long time period on the two tested cultivars.

The two eggplant cultivars affected the life table parameters of T.urticae The shortest mean generation time $(\mathrm{T})$ was 12.08 days on Black baity cultivar, and the longest was 13.21days on Baity cultivar .The highest net reproductive rate $\left(\mathrm{R}_{\mathrm{o}}\right)$ of T. urticae was 32.01 female/female on Black baity cultivar, and the lowest was $21.13 \mathrm{female} / \mathrm{female}$ on Baity cultivar. The intrinsic rate of natural increase $\left(\mathrm{r}_{\mathrm{m}}\right)$ of $T$. urticae recorded 0.28 and 0.23 female/female /day when reared on Black baity and Baity cultivars, respectively (table 5). The $r_{m}$ value is an important parameter, describing the growth potential of a population under food conditions, as it 
Table (1): Susceptibility of two eggplant cultivars to Tetranychus urticae infestation during 2011\&2012 seasons.

\begin{tabular}{lcccc}
\hline \multirow{2}{*}{ Eggplant cultivars } & \multicolumn{4}{c}{ Mean number of T. urticae movable stages / leaf } \\
\cline { 2 - 5 } & \multicolumn{3}{c}{ season 2011 } & \multicolumn{2}{c}{ season 2012 } \\
\cline { 2 - 5 } & Mean No. & Infestation\% & Mean No. & Infestation\% \\
\hline Black baity & $135.54^{\mathrm{a}} \pm 7.35$ & 63.25 & $115.03^{\mathrm{a}} \pm 11.29$ & 62.6 \\
\hline Baity & $78.73^{\mathrm{b}} \pm 4.67$ & 36.70 & $68.76^{\mathrm{b}} \pm 7.26$ & 37.41 \\
\hline LSD 0.05 & 15.5 & - & 9.75 & - \\
\hline
\end{tabular}

Table (2): Relationship between phytochemical components of two eggplant cultivar leaves and population of Tetranychus urticae adult stages.

\begin{tabular}{llccccc}
\hline \multirow{2}{*}{$\begin{array}{l}\text { Eggplant } \\
\text { cultivars }\end{array}$} & $\begin{array}{c}\text { Infestation } \\
\text { period }\end{array}$ & $\begin{array}{c}\text { Movable } \\
\text { stages } \\
\text { T.urticae }\end{array}$ & $\begin{array}{c}\text { Total } \\
\text { phenolic } \\
\text { (mgGAE/gm dw) }\end{array}$ & $\begin{array}{c}\text { Total amino acids } \\
\text { (mg alanine/gm } \\
\text { dw) }\end{array}$ & $\begin{array}{c}\text { Total } \\
\text { carbohydrates } \\
\text { (mg/mg dw) }\end{array}$ & $\begin{array}{c}\text { Tannins } \\
\text { (mgGAE/g } \\
\text { m dw) }\end{array}$ \\
\hline Black baity & Peak & 224.75 & 2.23 & 88.8 & 35.05 & 1.24 \\
& Late season & 58.34 & 2.44 & 89.3 & 36 & 1.38 \\
& Mean & 166.41 & 2.33 & 89.05 & 35.52 & 1.31 \\
\hline Baity & Peak & 149.99 & 2.85 & 82.14 & 29.30 & 1.60 \\
& Late season & 15.75 & 2.89 & 80.18 & 30.07 & 1.68 \\
& Mean & 134.24 & 2.87 & 81.16 & 29.68 & 1.64 \\
\hline
\end{tabular}

Table (3): Duration of developmental stages of

Tetranychus urticae reared on leaves of two eggplant cultivars at $25 \pm 1^{\circ} \mathrm{c}$.

\begin{tabular}{|c|c|c|c|}
\hline \multirow{3}{*}{$\begin{array}{l}\text { T.urticae } \\
\text { stages }\end{array}$} & \multirow{3}{*}{ Sex } & \multicolumn{2}{|c|}{ Duration in days } \\
\hline & & \multicolumn{2}{|c|}{ Eggplant cultivars } \\
\hline & & Black baity & Baity \\
\hline \multirow[t]{2}{*}{ Egg } & 오 & $3.13 \pm 0.08$ & $3.82 \pm 0.07$ \\
\hline & $0^{\pi}$ & $3.5 \pm 0.17$ & $3.87 \pm 0.11$ \\
\hline \multirow[t]{2}{*}{ Larva } & $q$ & $1.34 \pm 0.10$ & $2.04 \pm 0.07$ \\
\hline & $0^{\pi}$ & $1.125 \pm 0.11$ & $1.8 \pm 0.10$ \\
\hline \multirow[t]{2}{*}{ Protonymph } & $q$ & $2.21 \pm 0.08$ & $2.70 \pm 0.12$ \\
\hline & $\delta^{2}$ & $1.75 \pm 0.16$ & $2.11 \pm 0.11$ \\
\hline \multirow{2}{*}{ Deutonymph } & 오 & $2.09 \pm 0.06$ & $2.75 \pm 0.9$ \\
\hline & $0^{\pi}$ & $1.37 \pm 0.21$ & $2.1 \pm 0.12$ \\
\hline \multirow[t]{2}{*}{ Total immatures } & 오 & $5.64 \pm 0.28$ & $7.49 \pm 0.22$ \\
\hline & $\sigma^{2}$ & $4.37 \pm 0.15$ & $6.01 \pm 0.10$ \\
\hline \multirow[t]{2}{*}{ Life cycle } & 오 & $8.77 \pm 0.5$ & $11.31 \pm 0.2$ \\
\hline & $\delta^{3}$ & $7.74 \pm 0.15$ & $9.88 \pm 0.4$ \\
\hline \multirow[t]{2}{*}{ Adult longevity } & 오 & $11.08 \pm 0.9$ & $9.63 \pm 0.63$ \\
\hline & $\delta^{2}$ & $6.37 \pm 0.26$ & $5.87 \pm 0.29$ \\
\hline \multirow[t]{2}{*}{ Life span } & 우 & $20.54 \pm 0.5$ & $21.25 \pm 0.6$ \\
\hline & $\hat{0}$ & $14.11 \pm 0.2$ & $15.75 \pm 0.62$ \\
\hline
\end{tabular}

Table (4): Longevity and fecundity of Tetranychus urticae female on two eggplant cultivars

\begin{tabular}{|c|c|c|}
\hline \multirow{2}{*}{ Periods in days } & \multicolumn{2}{|c|}{ Eggplant cultivars } \\
\hline & Black baity & Baity \\
\hline Pre-oviposition & $1.18 \pm 0.09$ & $1.9 \pm 0.9$ \\
\hline Oviposition & $7.5 \pm 0.23$ & $5.2 \pm 0.2$ \\
\hline Post oviposition & $2.4 \pm 0.13$ & $2.5 \pm 0.13$ \\
\hline Adult longevity & $11.08 \pm 0.9$ & $9.53 \pm 0.63$ \\
\hline Fecundity & & \\
\hline No. of eggs / female & $43.26 \pm 2.06$ & $28.43 \pm 1.6$ \\
\hline Daily rate & $7.09 \pm 0.1$ & $5.0 \pm 0.9$ \\
\hline
\end{tabular}

Table (5): Effect of two eggplant cultivars on the life table parameters of Tetranychus urticae

\begin{tabular}{lcc}
\hline \multirow{2}{*}{ Parameters } & \multicolumn{2}{c}{ Eggplant cultivars } \\
\cline { 2 - 3 } & Black baity & Baity \\
\hline Generation time in day $(\mathrm{T})$ & 12.08 & 13.21 \\
\hline Net reproductive rate $\left(\mathrm{R}_{\mathrm{o}}\right)$ & 32.01 & 21.13 \\
\hline Intrinsic rate of natural increase $\left(\mathrm{r}_{\mathrm{m}}\right)$ per day & 0.28 & 0.23 \\
\hline Finite rate of increase $(\lambda)$ per day & 1.30 & 1.25 \\
\hline Sex ratio (female/total) & 73.00 & 74.00 \\
\hline
\end{tabular}




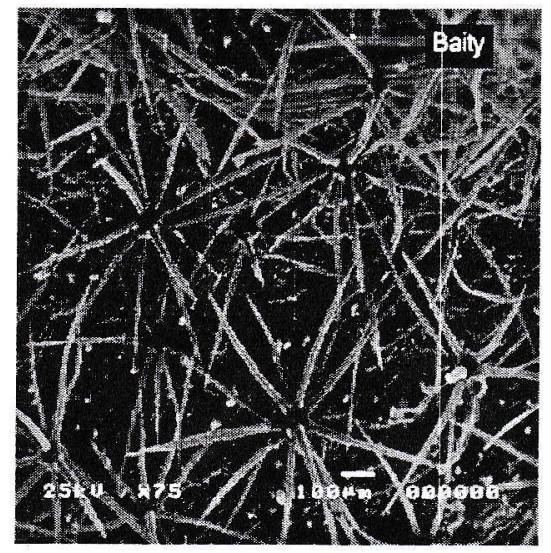

A

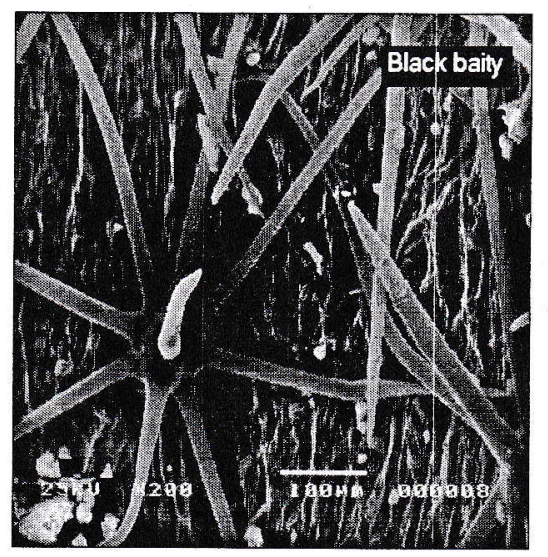

D

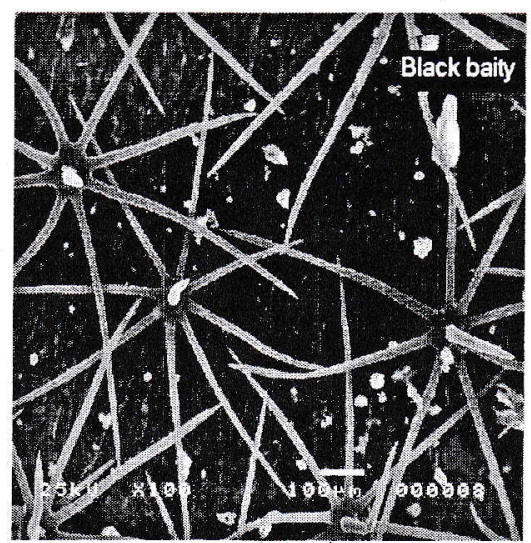

B

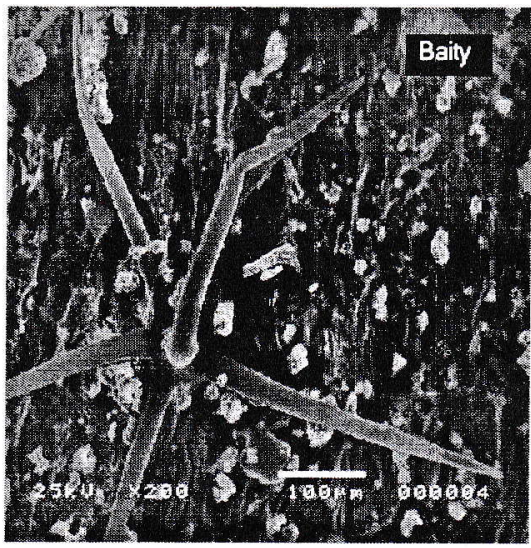

E

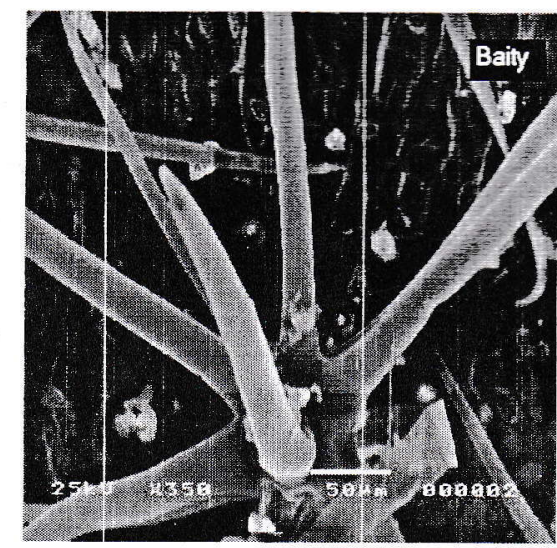

C

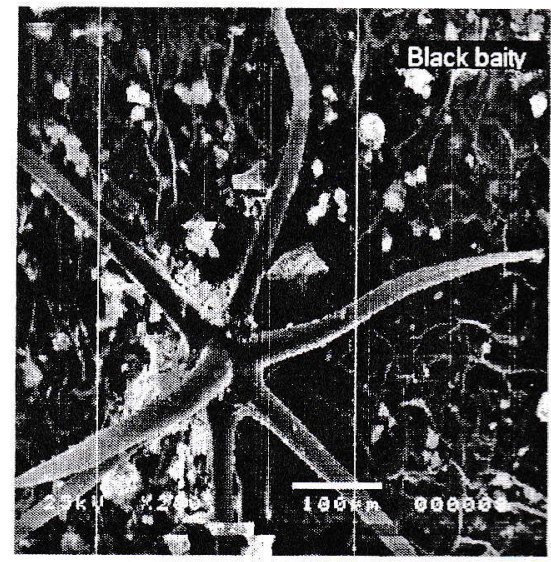

$\mathbf{F}$

Fig. (1): Scanning electron microscopy of leaves of two eggplant cultivars. A \& B: Shape and density of trichomes. C, D, E \& F: Trichome shape.

reflects the overall effects of food on development, reproduction and survival characteristic of the populations. These results are in agreement with those recorded by; Southwood, (1978) and Karrat (1991) .Ali and Zaher (2007) and Ali et al. (2013).

\section{REFERENCES}

Abdallah, A. A. 2002. Potential of predatory phytoseiid mites to control phytophagous mites. Ph.D. Thesis Imperial College, London Univ., U.K., 237 p.

Abdallah, A. A.; El-Saiedy, E. M. A.; El-Fatih, M. M. and Shoula, S. M. E. 2010. Effect of some biological and biochemical control agents against certain squash pests. Archives of phttopathology and plant protection, 45:73-82.

Abou-Setta, M. M.; Sorrell, R.W. and Childers, C. C. 1986. Life-48, a BASIC computer program to calculate life table parameters for an insect or mite species. Fla. Entomol., 69(4): 690- 697.

Afifi, A. M.; El-Laithy, A. Y. M.; Shehata, S. A. and El-Saiedy, E. M. A. 2009. Resistance of strawberry plants against the two-spotted spider mite, Tetranychus urticae Koch (Acari: Tetranychidae). Trends in Acarology, f.W.Sabelis \& J.Bruin (eds.), 505 -507.

Ali, F. S. and Zaher, M. A. 2007. Effect of food and temperature on the Biology of Typhlodrompis swirskii (Athias-Henrioi) (Acari: Phytoseiidae). Acarines, 1: 17-21.

Ali, F. S.; Afifi, Å.M.; El-Saiedy, E.M.A. and Ahmed M.M. 2013. Biology and life table parameters of Tetranychus urticae Koch (Acari:Tetranychidae) and two Phytoseiid predatory mites on two Watermelon cultivars. Acarines, 7: 15-20.

Birch, L.C.1948. The intrinsic rate of natural increase of an insect population. J. Arum. Ecol., 17: $15-26$.

Crompton, M. and Birt, L. M.1967.changes in the amounts of carbohydrates. Phoshagen, and related compounds during the metamorphosis of the blowfly,Lucilia cuprina. J. Insect Physiol., 13:1575-1595.

Crooker, A.1985. "Embryonic and juvenile development". In: Spičer Mites. Their Biology, Natural Enemies and Control (Eds. Helle, W. \& 
Sabelis, M. W.), Elsevier, Amsterdam, World Crop Pests, 1: 149-163.

El-Saiedy, E. M. A. and Romeih, H. M. 2007. Comparative studies between predatory mites and pesticides in controlling Tetranychus urticae Koch on strawberry plants at Qalubia Governorate. J. Agric. Sci. Mansoura Univ., 32(4): 2601-2608.

El-Saiedy, E. M. A.; Afifi, A. M.; Ali, F S. and Ahmed, M. M. 2011. Susceptibility of four Watermelon cultivars to infestation with Tetranychus urticae Koch. Acarines, 5(1): 23-28.

Fashing, N. J.; Ocon:or, B. M and Kitching, R. L. 2000. Lamingtona carus, a new genus of Algophagidae (Acari: Astigmata) from water filled treehotes in queensland. Australia. Invertebrate Taxonomy, 14 (4):591-606.

Filgueira, F. A. R. 2000. Novo Manual de Olericultura. Universidade Federal de Vicosa, Vicosa, 402 pp.

Ibrahim, M. M. S.; El-Esnawy, B. A. and El-Adawy, A. M., 2008. Imbrications of certain cucurbit crops characteristics with the two-spotted spider mite infestation. Acarines, 2: 61-65.

Karaat, Ş.1991. Biological Parameters and Population Changes of Tetranychus urticae Koch on Various Cotton Varieties Sought to be cultured in Southeastern Anatolia. Ph.D. Thesis, Çukurova Univ. Institute of Natural and Applied Sci., Adana, 62 p.

Lee, Y. P. and Takabashi, T. 1966. An improved colorimetric determination of amino acids with the use of ninhydrin. Anal.Biochem., 14:71-77.

Leite, G. L. D.; Picanco, M.; Zanuncio, J. C. and Marquini, F.2003. Factors affecting mite herbivory on eggplants in Brazil. Experimental and Applied Acarology, 31(3/4) : 243-252.

Patrick, C.; Jafer, M. and Luc, T. 2000. Effect of host plant functional respons of the predator Podisus nigrispiinus on tomato. Bio. Cont., 18(1):65-70.

Singleton,V.L. and Rossi,J.A.1965. Colorimetry of total phenolies with phosphomolybdicphosphotungstic acid reagents. Am. J.Enol. Vitic., 16:144-158.

Southwood, T. R. E.1978. Ecological Methods. Chapman and Hall, New York, 524p.

Tomczyk, A.; Kropczynska, D. and Kielkiewicz, M. 1987. Manifestations of resistance to spider mites in cultivated plants. Materialy XXVII Sesjinaukowej Instytutu Ochrony Roslin. Czese I. Referaty, 34: 65-79. 